\title{
Increased expression of HIF-1A and its implication in the hypoxia pathway in primary advanced uterine cervical carcinoma
}

\author{
MICHAŁ W. UUCZAK $^{1}$, ANDRZEJ ROSZAK ${ }^{4}$, PIOTR PAWLIK ${ }^{2,3}$, \\ HELENA KĘDZIA $^{3}$, MARGARITA LIANERI ${ }^{1}$ and PAWEŁ P. JAGODZIŃSKI ${ }^{1}$
}

Departments of ${ }^{1}$ Biochemistry and Molecular Biology, ${ }^{2}$ Surgical Gynecology, and ${ }^{3}$ Pathology, Poznań University of Medical Sciences; ${ }^{4}$ Department of Radiotherapy and Gynecological Oncology, Greater Poland Cancer Centre Poznań, Poznań, Poland

Received May 9, 2011; Accepted June 6, 2011

DOI: 10.3892/or.2011.1397

\begin{abstract}
The development of cervical cancer exhibits some unique differences compared to other solid tumors. Normal cervical stratified epithelia have characteristics of hypoxic tissue. Lack of oxygen (hypoxia) induces the HIF-1 (hypoxiainducible factor-1) transcription factor, which is a heterodimer composed of a constitutively expressed $\beta$ subunit and a hypoxia-inducible $\alpha$-subunit. HIF-1A targets the transcription of over 70 genes involved in many aspects of cancer biology. In well-oxygenated environments, the HIF-1A subunit is hydroxylated, recognized and marked for proteosomal destruction by an E3 ubiquitin ligase, the von Hippel-Lindau protein (pVHL) complex. Under hypoxic stress, proline hydroxylase (PHD) activity is diminished, and stabilized HIF-1A is involved in the activation of the tissue response to hypoxia. Here, we examined the HIF-1A and VHL transcript levels and HIF-1A protein levels in cancerous tissue $(n=30)$ and non-cancerous, normal uterine cervical tissue $(n=30)$. We also compared the methylation status of HIF-1A and of the VHL promoter regions in cancerous and normal tissue samples. Significantly higher levels of HIF-1A and VHL transcripts $(\mathrm{p}<0.0001$ and $\mathrm{p}=0.0042$, respectively) and of HIF-1A protein $(\mathrm{p}=0.0037)$ were detected in cancerous tissue compared to normal samples. We did not observe DNA methylation in the HIF-1A and VHL promoter region in either control or cancerous tissue samples. VHL has a functional hypoxia response element (HRE) in the promoter region, and the induction of this HRE acts within a negative feedback loop to limit the hypoxic HIF-1A response. Our findings may suggest that HIF-1A could promote its own degradation by the induction of VHL gene expression (Spearman correlation coefficient, $0.515 ; \mathrm{p}=0.003$ ). Our study shows for the first time that this increase in VHL expression
\end{abstract}

Correspondence to: Dr Michał W. Łuczak, Department of Biochemistry and Molecular Biology, Poznań University of Medical Sciences, 6 Święcickiego Street, 60-781 Poznań, Poland

E-mail:mluc@ump.edu.pl

Key words: cervical cancer, hypoxia, hypoxia-inducible factor-1A, von Hippel-Lindau could be HIF-1A-dependent and serves within a negative feedback pathway during hypoxia to regulate the cell-specific oxygen threshold for HIF-1A activation.

\section{Introduction}

Cervical cancer is a significant cause of death in women worldwide and remains one of the most common cancers in women in developing countries (1). The main histological type is squamous cell carcinoma, which accounts for approximately two-thirds of all cervical cancer cases, whereas adenocarcinoma and adenosquamous carcinomas account for $10-25 \%$ of cases (1). The primary etiological factor associated with cervical cancer development is exposure to human papillomavirus (HPV), particularly types 16 and 18 (2). Despite a relatively high prevalence of HPV in the cervix, the development of cervical cancer occurs after a long period of viral persistence. This suggests that additional genetic and epigenetic alterations as well as other factors may be required to maintain a malignant phenotype in the cervix (3).

Human solid tumors contain hypoxic regions that have a considerably lower oxygen tension than healthy tissues (4). Lack of oxygen (hypoxia) is a hallmark of solid tumor formation and constitutes an independent prognostic factor in a diverse range of malignant tumors (5). Hypoxia induces hypoxia-inducible factor-1 (HIF-1), which has been identified as an important transcription factor that mediates the cellular response to hypoxia. HIF-1 protein is a heterodimer composed of a constitutively expressed $\beta$ subunit (ARNT, aryl hydrocarbon receptor nuclear translocator) and a hypoxia-inducible $\alpha$-subunit (HIF-1A) (6). In well-oxygenated environments, HIF-1A subunits are hydroxylated at the conserved proline $\mathrm{Pro}^{402}$ and $\mathrm{Pro}^{564}$ residues. These modifications are mediated by proline hydroxylases (PHDs), whose activities are regulated by $\mathrm{O}_{2}$ availability (7). Hydroxylated HIF-1A is, in turn, recognized and marked for proteosomal destruction by an E3 ubiquitin ligase, the von Hippel-Lindau protein (pVHL) complex (8). Under hypoxic stress, PHD activity is diminished, and stabilized HIF-1A is involved in the activation of numerous cellular processes including resistance to apoptosis, overexpression of several glycolytic protein and drug efflux membrane pumps, vascular remodeling, angiogenesis, and even metastasis $(9,10)$. Furthermore, tumoral HIF-1A overexpression is often associated with poor prognosis and is 
observed in a vast number of solid tumors (11-15). On the other hand, inhibition of HIF-1A by means of RNA interference or pharmacological compounds has demonstrable antitumoral efficacy in various murine cancer models (16). However, the underlying molecular mechanisms of, as well as the role of HIF-1A in, drug resistance under normoxic conditions remain largely elusive (6).

Here, we studied the expression of HIF-1A (transcript and protein level) in cancerous tissue $(n=30)$ and non-cancerous (normal) uterine cervical tissue $(n=30)$ from a Polish cohort. We also compared, in cancerous and non-cancerous tissues, the VHL transcript level and the methylation status of HIF-1A and VHL promoter regions.

\section{Materials and methods}

Tissue samples. Cervical cancer (cancerous tissue) and non-cancerous (normal tissue) samples were collected from Caucasian women of the Wielkopolska district of Poland and represent the female Polish population. Samples were collected from patients undergoing gynecological procedures at the Department of Radiotherapy, Greater Poland Cancer Center in Poznań, Poland. Normal uterine cervical samples were obtained from women with uterine surgical resection in the Department of Surgical Gynecology, Poznań University of Medical Sciences, Poland. Cervical samples $(n=30)$ and non-tumor specimens $(n=30)$ were collected following approval by the Local Ethics Committee of Poznań University of Medical Sciences.

Cancer cells and all specimens underwent initial H\&E staining (17), followed by review by an experienced pathologist. Cervical sections with cancer cells were used as cancer samples. The same criteria were applied to identify normal cervical tissue samples. After surgical removal, tissue samples were frozen in liquid nitrogen and stored at $-80^{\circ} \mathrm{C}$ until used. All 30 studied patients had squamous cell carcinoma (SCC). Among 30 patients with SCC, 1 patient was classified as stage II, 28 as stage III and 1 as stage IV, based on the International Federation of Gynecology and Obstetrics (FIGO) classification system (Table I).

Antibodies. Rabbit polyclonal anti-HIF-1A antibody (Ab) (H-206) raised against amino acids 575-780 of human HIF-1A, goat anti-rabbit IgG-HRP -conjugated $\mathrm{Ab}$, and goat anti-actin HRP-conjugated Ab (clone I-19) were provided by Santa Cruz Biotechnology (Santa Cruz, CA). The molecular weights of HIF-1A and $\beta$-actin are 120 and $43 \mathrm{kDa}$, respectively.

Reverse-transcription and real-time quantitative $P C R$ (RQ-PCR) analysis of HIF-1A and VHL transcripts. Total RNA from normal and cancerous tissue samples was isolated according to the method of Chomczynski and Sacchi (18). RNA integrity was confirmed by denaturing agarose gel electrophoresis, and the concentration was quantified by measuring the optical density (OD) at $260 \mathrm{~nm}$. RNA samples were treated with DNase I and reverse-transcribed into cDNA using oligo-dT primers.

RQ-PCR was conducted in a real-time PCR-CFX96 detection system Bio-Rad Laboratories (CA, USA) using iQ SYBR-Green as detection dye, and target cDNA was quantified by a relative quantification method using a calibrator. For
Table I. Clinical characteristics of patients with cervical cancer and healthy controls.

\begin{tabular}{lcc}
\hline Characteristics & $\begin{array}{c}\text { Patients } \\
(\mathrm{n}=30)\end{array}$ & $\begin{array}{c}\text { Controls } \\
(\mathrm{n}=30)\end{array}$ \\
\hline $\begin{array}{l}\text { Mean age (years) } \pm \mathrm{SD} \\
\text { Tumor stage, } \mathrm{n}(\%)\end{array}$ & $52.6 \pm 11.7$ & $48.2 \pm 6.8$ \\
II & $1(3.3)$ & \\
III & $28(93.4)$ & \\
IV & $1(3.3)$ & \\
Histological grade, $\mathrm{n}(\%)$ & & \\
G1 & $1(3.3)$ & \\
G2 & $18(60.0)$ \\
G3 & $11(36.7)$ \\
\hline
\end{tabular}

the calibrator, $1 \mu \mathrm{l}$ of cDNA from all samples were mixed together. To create a standard curve, successive dilutions were used as described in the Relative Quantification Manual Roche Diagnostics GmbH (Mannheim, Germany). The quantity of HIF-1A and VHL transcripts in each sample was standardized by the PBGD transcript level. For amplification, $1 \mu \mathrm{l}$ of total (20 $\mu \mathrm{l}$ ) cDNA solution was added to $5 \mu \mathrm{l}$ of iQ SYBR-Green Supermix (Bio-Rad Laboratories) and primers for HIF-1A, VHL and PBGD transcripts (Table II). One RNA sample of each preparation was processed without RT-reaction to provide a negative control in subsequent PCR.

Sodium dodecyl sulfate-polyacrylamide gel electrophoresis (SDS-PAGE) and Western blot analysis. Normal and cancerous tissue samples were treated with the RIPA lysis buffer. Protein concentration was quantified using Bradford method according to manufacturer protocol (Bio-Rad Laboratories GmbH, Munich, Germany). Next, $30 \mu \mathrm{g}$ of protein were resuspended in sample buffer and separated on $10 \%$ Tris-glycine gel using SDS-PAGE. Gel proteins were semi-dry transferred to PVDF membranes (Roche Diagnostics, Mannheim, Germany), which were blocked with 5\% milk in Tris-buffered saline/Tween. Immunodetection was performed with anti-HIF-1A antibody (H-206), followed by incubation with the goat anti-rabbit IgG-HRP-conjugated antibody. As a loading control, the blots were stripped and reprobed with a goat anti-actin HRP-conjugated antibody (clone I-19). Bands were revealed using the SuperSignal West Femto Maximum Sensitivity Substrate Pierce (Rockford, IL) and Hyperfilm ECL Amersham (Piscataway, NJ).

Sodium bisulfite DNA sequencing of the HIF-1A and VHL promoter region. Genomic DNA from normal and cancerous tissues was extracted using a salting-out method. Extracted DNA was treated using the EZ DNA Methylation Kit ${ }^{\mathrm{TM}}$ (Zymo Research Corp., Orange, CA), according to the manufacturer's protocol. The location of the $\mathrm{CpG}$ islands in the promoter regions of HIF-1A and VHL genes were determined by an online program found at http://www.ebi.ac.uk/emboss/cpgplot/. The promoter regions containing $\mathrm{CpG}$ islands were amplified by the primer pairs (Table II) complementary to the modified 
Table II. Primer pairs used for DNA amplification of studied gene fragments.

\begin{tabular}{|c|c|c|c|c|}
\hline Gene & Sequence (5'-3' direction) & Position & ENST no. & Product size (bp) \\
\hline HIF-1A & $\begin{array}{l}\text { TTAGAACCAAATCCAGAGTCAC } \\
\text { TATTCACTGGGACTATTAGGCT }\end{array}$ & $\begin{array}{l}\text { Exon } 10 \\
\text { Exon } 10 / 11\end{array}$ & 00000337138 & 125 \\
\hline HIF-1A & $\begin{array}{l}\text { TGATGTATGTTTGGGATTAGG } \\
\text { AАCСTCTCCTCAAATAACTTA }\end{array}$ & $\begin{array}{l}\text { Promoter } \\
5 \text { 'UTR }\end{array}$ & 00000337138 & 530 \\
\hline VHL & $\begin{array}{l}\text { AACGGATGGGAGATTGAAGATT } \\
\text { CAATGCCTAGTGAAGTCAGTTA }\end{array}$ & $\begin{array}{l}\text { Exon } 1 \\
\text { Exon } 2\end{array}$ & 00000256474 & 183 \\
\hline VHL & $\begin{array}{l}\text { AATTTTATAGTGGAAATATAGTA } \\
\text { TACCTCAAAAAACCTCAATTC }\end{array}$ & $\begin{array}{l}\text { Promoter } \\
\text { Intron } 1\end{array}$ & 00000256474 & 701 \\
\hline PBGD & $\begin{array}{l}\text { GCCAAGGACCAGGACATC } \\
\text { TCAGGTACAGTTGCCCATC }\end{array}$ & $\begin{array}{l}\text { Exon } 11 \\
\text { Exon } 12 / 13\end{array}$ & 00000278715 & 160 \\
\hline
\end{tabular}

Table III. HIF-1A transcript ${ }^{\mathrm{a}}$ and protein ${ }^{\mathrm{b}}$ levels in advanced uterine cervical carcinoma and corresponding normal tissues.

\begin{tabular}{|c|c|c|c|c|c|}
\hline & \multicolumn{2}{|c|}{ Normal tissue } & \multicolumn{2}{|c|}{ Cancerous tissue } & \multirow[b]{2}{*}{ p-value } \\
\hline & Median (range) & Mean $( \pm S D)$ & Median (range) & Mean $( \pm \mathrm{SD})$ & \\
\hline \multirow[t]{2}{*}{ HIF-1A } & $0.34(0.01-0.97)^{\mathrm{a}}$ & $0.36 \pm 0.29^{\mathrm{a}}$ & $1.12(0.20-1.87)^{\mathrm{a}}$ & $1.09 \pm 0.57^{\mathrm{a}}$ & $0.0001^{\mathrm{a}}$ \\
\hline & $0.42(0.07-1.78)^{\mathrm{b}}$ & $0.60 \pm 0.46^{\mathrm{b}}$ & $0.91(0.10-4.70)^{\mathrm{b}}$ & $1.20 \pm 0.99^{b}$ & $0.0037^{\mathrm{b}}$ \\
\hline VHL & $0.80(0.27-1.94)^{\mathrm{a}}$ & $0.83 \pm 0.37^{\mathrm{a}}$ & $1.09(0.21-2.55)^{\mathrm{a}}$ & $1.22 \pm 0.61^{\mathrm{a}}$ & $0.0042^{\mathrm{a}}$ \\
\hline
\end{tabular}

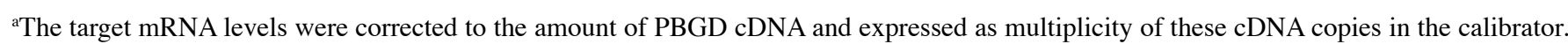
${ }^{\mathrm{b}}$ The amount of Western blot-detected proteins was presented as the HIF-1A-to- $\beta$-actin band optical density ratio. ${ }^{\mathrm{c}}$ Unpaired, two-tailed t-test.

DNA. PCR amplification was conducted by the FastStart Taq DNA Polymerase from Roche Diagnostic GmbH, (Penzberg, Germany). The PCR products were purified using the Agarose Gel DNA Extraction Kit (Roche) and cloned into the pGEM-T Easy Vector System I (Promega, Madison, WI) following transformation into TOPO10 E. coli strain cells. Plasmid DNA isolated from ten positive bacterial clones was used for commercial sequencing of the cloned fragments of DNA.

Statistical analysis. Data groups for cell lines were assessed by ANOVA to evaluate if there was significant differences $(\mathrm{p}<0.05)$ between the groups. For all experimental groups, which fulfilled the initial criterion, individual comparisons were performed by the post-hoc Tukey test with the assumption of a two-tailed distribution and two samples with equal variance at the $\mathrm{p}<0.05$ level. The normality of the observed patient data distribution was assessed by the Shapiro-Wilk test and the unpaired, twotailed t-test was used to compare the mean values. $\mathrm{p}<0.05$ was considered statistically significant. Spearman's rank correlation was used to determine whether a correlation between the expression of the analyzed genes was positive or negative.

\section{Results}

Increased HIF-1A expression in advanced uterine cervical carcinoma induces expression of VHL and is not associated with epigenetic regulation. RQ-PCR and Western blot analysis were used to compare HIF-1A and VHL transcript and HIF-1A protein levels in normal and cancerous tissues. Our results show significantly higher levels of HIF-1A and VHL transcript $(\mathrm{p}<0.0001$ and $\mathrm{p}=0.0042$, respectively) and HIF-1A protein $(p=0.0037)$ levels in cancerous tissue compared to normal tissue samples (Fig. 1A, B, and D; Table III). We did not find significant differences between transcript and protein levels between patient groups with different tumor stage and histological grade. We also did not observe DNA methylation in the HIF-1A and VHL promoter region in either control or cancerous tissues samples (results not shown). A statistically significant association was found between HIF-1A and VHL expression (Spearman correlation coefficient $=0.515, \mathrm{p}=0.003$ ).

\section{Discussion}

Cervical cancer exhibits some unique characteristics that are different from other solid tumors. Healthy stratified epithelia, including cervical cells, have characteristics of chronically hypoxic tissue (19-21). Increased vascularity is observed in low grade cervical cancer, while this is usually a late event in the progression of many other cancers $(20,22)$. Tissue hypoxia is a common feature of most solid tumors $(15,23,24)$, often with heterogeneous $\mathrm{O}_{2}$ levels within different regions of the individual tumors. The cellular adaptation to hypoxic 
A

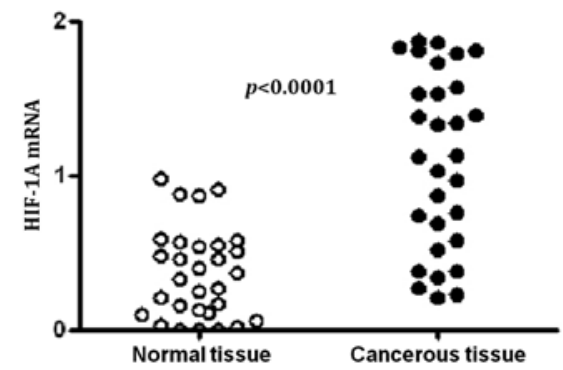

B

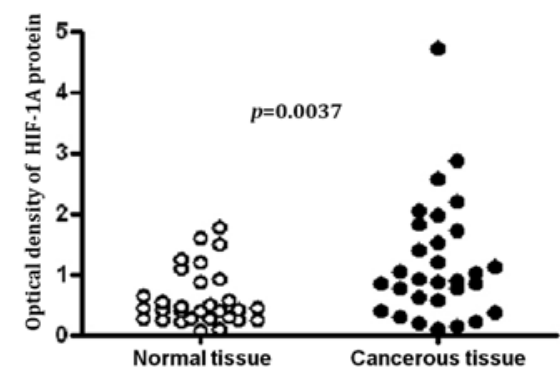

C

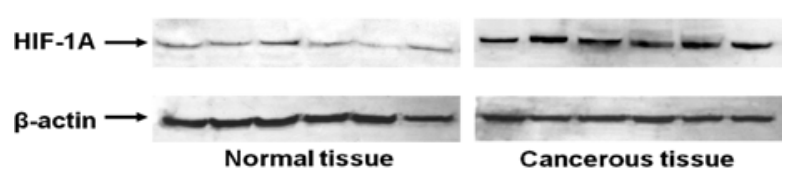

D

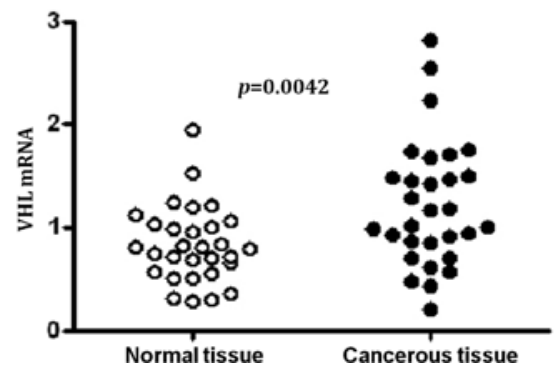

Figure 1. HIF-1A (A), VHL (D) transcript and HIF-1A protein (B) levels. (C) Represents a sample picture of Western blot analysis of HIF-1A protein levels in advanced uterine cervical carcinoma and non-cancerous, normal tissues.

stress is highly complex and depends on the up-regulation of genes supporting anaerobic metabolism and new blood vessel recruitment (25).

Under hypoxic conditions, cells secrete a variety of cytokines and growth factors that induce proliferation, migration, and blood vessel formation by endothelial cells (26). The cellular response to hypoxia is primarily regulated through the activity of the HIF-1 (27) transcriptional factor, which targets the transcription of over 70 genes (28). Other factors independent of hypoxia can also promote HIF-1A protein accumulation via translational or post-translational mechanisms (28). Several studies have shown that many human cancers express an elevated level of HIF-1A protein, which is closely associated with a more aggressive tumor phenotype (29-32) and offers resistance to radiotherapy and anticancer chemotherapy $(33,34)$.

Rapid degradation of the ubiquitinated HIF-1A is considered the principal mechanism through which HIF-dependent transcription is suppressed during normoxia. The inhibition of PHDs activity due to decreased oxygen levels is considered critical for HIF-1 A escape from proteosome degradation during hypoxia because the affinity of VHL for the non-hydroxylated HIF-1A is much lower (35-37). Our previous research and that published by Roszak et al (38) show for the first time a full analysis of the hypoxia pathway in primary advanced uterine cervical carcinoma.

Normal cervical tissue has characteristics of hypoxic tissue (19-21) with partial stabilization of HIF-1A protein. This stabilization increases during carcinogenesis and the progression of cervical cancer. Fujimoto et al (39) reported that HIF-1A mRNA levels increase significantly with increasing disease stage. Similar data was presented by No et al (40) using the immunohistochemical method and paraffin-embedded specimens. HIF-1A expression was higher in cervical intraepithelial neoplasia and invasive cancer as compared to the corresponding normal uterine cervical tissues (40).

Overexpression of HIF-1A was described in many solid tumors such as gastric (23), gallbladder (24), colon, breast, lung, skin, ovarian, pancreatic, prostate and renal carcinoma (15). High expression of HIF-1A was also reported in cervical cancer tissue samples $(21,39-47)$, but only using the immunohistochemical method.

Furthermore, increased expression of HIF-1A is associated with low oxygen partial pressure $\left(\mathrm{pO}_{2}\right)$ in tissue samples. Hutchison et al (44) and Haugland et al (46) found significant correlations between immunohistochemically detected HIF-1A and low $\mathrm{pO}_{2}$ in a group of 72 and 42 patients, respectively, with cervical carcinoma. Similarly, correlation between low $\mathrm{pO}_{2}$ and high immunohistochemically detected HIF-1A was also described in advanced head and neck cancer (48). Decreased $\mathrm{pO}_{2}$ in cancerous tissue favors HIF-1A accumulation during hypoxia because $\mathrm{PDH} 2$ expression is depleted at low oxygen levels (38).

We are the first to analyze HIF-1A transcript and protein levels in groups of patients with primary advanced uterine cervical carcinomas and normal, healthy uterine cervical tissues. We found a significantly increased level of HIF-1A and VHL transcripts (Fig. 1A and D respectively, Table III) in advanced uterine cervical carcinomas as compared to the corresponding normal uterine cervical tissues. A similar correlation was found in HIF-1A protein levels detected using Western blot technique in tumor tissue samples and their normal, non-cancerous counterpart (Fig. 1B and C; Table III).

To date, expression of the VHL gene had not been reported in cervical cancer. The levels of the VHL transcript are increased in cervical carcinoma, which is the opposite of the demonstrated lower expression of VHL in renal cell carcinoma (49), multiple myeloma (50), pancreatic endocrine tumors (51), chronic lymphocytic leukemia (52) and squamous cell carcinoma of the vulva (53). The observed abnormal expression of VHL in cervical cancer could be associated with increased levels of HIF-1A, because we found a statistically significant, positive Spearman's rank correlation between HIF-1A and VHL expression.

Renbaum et al (54) were the first to report that the VHL 3'-untranslated region contains consensus HIF-1 binding sites. Blagosklonny (55) suggested the ability of the HIF-1 transcription factor to transactivate the VHL gene, which would establish a feedback loop. Finally, Karhausen et al (56) reported the induction of VHL gene expression by HIF-1A 
transcription factor in the HeLa cervical cancer cell line. These authors documented the direct HIF-1A binding to the VHL promoter and identified a functional hypoxia response element (HRE) within the VHL promoter. These results implicate a physiologically relevant feedback mechanism whereby HIF self-regulates its expression through VHL (56). Our findings may suggest that HIF-1A could promote its degradation by the induction of VHL gene expression and could also be a first step to prove Blagosklonny's (55) hypothesis at the patient level in cervical cancer.

Referring to Pescador et al (57) and Metzen et al (58), prolyl hydroxylases (PHD3 and PHD2) have a functional HRE in their promoter region, and its induction acts within a negative feedback loop to limit the hypoxic HIF-1 response. Henze et al (59) reported that PHD2 and PHD3 were induced by hypoxia in human glioblastomas and that PHDs protect against hypoxiainduced cell death. Ginouves et al (60) provided evidence that the hypoxic PHDs accumulation in human fibrosarcoma, breast and colon cancer cell lines, primary cultures of human dermal fibroblasts and human epidermal keratinocytes and in the animal, murine model, acts within a negative feedback loop to limit the HIF-1 response during conditions of reduced oxygen availability. A direct, negative regulatory mechanism, which limits accumulation of HIF-1A in hypoxia through induction of PHDs, has been reported by several investigators (61-67). In our previously published report (38) we found significantly lower levels of PHD2 transcript and protein levels in cancerous tissue than in the corresponding normal tissue. We did not observe a negative feedback loop to limit HIF-1 via induction of PHDs. We can explain this result by analyzing the promoter region of PHD2. The majority of the HREs of hypoxia induced genes contains a HIF-1 ancillary sequence (HAS), which is located 8-9 nucleotides down- or upstream of hypoxia binding sites and is necessary for HIF-1A mediated transcription activation (68). Furthermore, efficient gene activation requires recruiting of additional transcriptional factors, such as ATF-1/CREB-1, AP-1 and HNF-4 factor (69), which are not hypoxia dependent. Wenger et al (28) also reported that nucleotides located close to HRE in the promoter sequence can also affect HIF-1 gene activation. Therefore, mutations present in the promoter region of the PHD2 gene could perturb the negative feedback loop of the hypoxia pathway. We found single nucleotide mutations in the PHD2 promoter, which normally provides binding sites for transcription factors (38). These mutations may remove binding sites for transcription factors, which are required for hypoxia HIF-1A induced expression (69) of PHD2.

In conclusion, we demonstrate increased HIF-1A, VHL transcript and HIF-1A protein levels in advanced uterine cervical carcinoma. We also observe that the increase in VHL expression could be HIF-1A-dependent and serves within a negative feedback pathway during hypoxia to regulate the cell-specific oxygen threshold for HIF-1A activation. However, further studies are required to elucidate the negative feedback pathways in cervical cancer.

\section{Acknowledgements}

This study was supported by grant no. N N407 049538 from the Polish Ministry of Scientific Research and Information Technology.

\section{References}

1. Liyanage SH, Roberts CA and Rockall AG: MRI and PET scans for primary staging and detection of cervical cancer recurrence. Womens Health 6: 251-267, 2010.

2. Smith JS, Lindsay L, Hoots B, et al: Human papillomavirus type distribution in invasive cervical cancer and high-grade cervical lesions: a meta-analysis update. Int J Cancer 121: 621-632, 2007.

3. Kisseljov F, Sakharova O and Kondratjeva T: Cellular and molecular biological aspects of cervical intraepithelial neoplasia. Int Rev Cell Mol Biol 271: 35-95, 2008.

4. Harada H, Kizaka-Kondoh S, Li G, Itasaka S, Shibuya K, Inoue $M$ and Hiraoka M: Significance of HIF-1-active cells in angiogenesis and radioresistance. Oncogene 54: 7508-7516, 2007.

5. Vaupel P, Mayer A and Höckel M: Tumor hypoxia and malignant progression. Methods Enzymol 381: 335-354, 2004.

6. Unruh A, Ressel A, Mohamed HG, et al: The hypoxia-inducible factor-1 alpha is a negative factor for tumor therapy. Oncogene 22: 3213-3220, 2003

7. Kaelin WG Jr and Ratcliffe PJ: Oxygen sensing by metazoans: the central role of the HIF hydroxylase pathway. Mol Cell 30: 393-402, 2008

8. Majmundar AJ, Wong WJ and Simon MC: Hypoxia-inducible factors and the response to hypoxic stress. Mol Cell 40: 294-309, 2010.

9. Marín-Hernández A, Gallardo-Pérez JC, Ralph SJ, RodríguezEnríquez S and Moreno-Sánchez R: HIF-lalpha modulates energy metabolism in cancer cells by inducing over-expression of specific glycolytic isoforms. Mini Rev Med Chem 9: 1084-1101, 2009.

10. Weidemann A and Johnson RS: Biology of HIF-1alpha. Cell Death Differ 15: 621-627, 2008.

11. Liu L, Ning X, Sun L, et al: Hypoxia-inducible factor-1 alpha contributes to hypoxia-induced chemoresistance in gastric cancer. Cancer Sci 99: 121-128, 2008.

12. Sullivan R, Paré GC, Frederiksen LJ, Semenza GL and Graham CH: Hypoxia-induced resistance to anticancer drugs is associated with decreased senescence and requires hypoxiainducible factor-1 activity. Mol Cancer Ther 7: 1961-1973, 2008.

13. Sasabe E, Zhou X, Li D, Oku N, Yamamoto T and Osaki T: The involvement of hypoxia-inducible factor-lalpha in the susceptibility to gamma-rays and chemotherapeutic drugs of oral squamous cell carcinoma cells. Int J Cancer 120: 268-277, 2007.

14. Brown LM, Cowen RL, Debray C, et al: Reversing hypoxic cell chemoresistance in vitro using genetic and small molecule approaches targeting hypoxia inducible factor-1. Mol Pharmacol 69: 411-418, 2006.

15. Zhong H, De Marzo AM, Laughner E, et al: Overexpression of hypoxia-inducible factor 1alpha in common human cancers and their metastases. Cancer Res 59: 5830-5835, 1999.

16. Patiar S and Harris AL: Role of hypoxia-inducible factor-1alpha as a cancer therapy target. Endocr Relat Cancer 13: S61-S75, 2006.

17. Puchtler H, Meloan SN and Waldrop FS: Application of current chemical concepts to metal-hematein and -brazilein stains. Histochemistry 85: 353-364, 1986.

18. Chomczynski P and Sacchi N: Single-step method of RNA isolation by acid guanidinium thiocyanate-phenol-chloroform extraction. Anal Biochem 162: 156-159, 1987.

19. Lee WY, Huang SC, Hsu KF, Tzeng CC and Shen WL: Roles for hypoxia-regulated genes during cervical carcinogenesis: somatic evolution during the hypoxia-glycolysis-acidosis sequence. Gynecol Oncol 108: 377-384, 2008.

20. Mazibrada J, Rittà M, Mondini M, et al: Interaction between inflammation and angiogenesis during different stages of cervical carcinogenesis. Gynecol Oncol 108: 112-120, 2008.

21. Mayer A, Wree A, Höckel M, Leo C, Pilch H and Vaupel P: Lack of correlation between expression of HIF-1alpha protein and oxygenation status in identical tissue areas of squamous cell carcinomas of the uterine cervix. Cancer Res 64: 5876-5881, 2004.

22. Smith-McCune KK and Weidner N: Demonstration and characterization of the angiogenic properties of cervical dysplasia. Cancer Res 54: 800-804, 1994.

23. Nam SY, Ko YS, Jung J, et al: A hypoxia-dependent upregulation of hypoxia-inducible factor- 1 by nuclear factor- $\kappa \mathrm{B}$ promotes gastric tumour growth and angiogenesis. $\mathrm{Br} \mathrm{J}$ Cancer 10: 166-174, 2011.

24. Batmunkh E, Shimada M, Morine Y, et al: Expression of hypoxia-inducible factor-1 alpha (HIF-1alpha) in patients with the gallbladder carcinoma. Int J Clin Oncol 15: 59-64, 2010. 
25. Coulon C, Georgiadou M, Roncal C, De Bock K, Langenberg T and Carmeliet P: From vessel sprouting to normalization: role of the prolyl hydroxylase domain protein/hypoxia-inducible factor oxygen-sensing machinery. Arterioscler Thromb Vasc Biol 30: $2331-2361,2010$.

26. Brat DJ, Kaur B and Van Meir EG: Genetic modulation of hypoxia induced gene expression and angiogenesis: relevance to brain tumors. Front Biosci 8: D100-D116, 2003.

27. Bárdos JI and Ashcroft M: Negative and positive regulation of HIF-1: a complex network. Biochim Biophys Acta 1755: 107-120, 2005.

28. Wenger RH, Stiehl DP and Camenisch G: Integration of oxygen signaling at the consensus HRE. Sci STKE 306: re12, 2005.

29. Dales JP, Beaufils N, Silvy M, et al: Hypoxia inducible factor 1alpha gene (HIF-1alpha) splice variants: potential prognostic biomarkers in breast cancer. J BMC Med 8: 44, 2010.

30. Henze AT and Acker T: Feedback regulators of hypoxiainducible factors and their role in cancer biology. Cell Cycle 14: 2749-2763, 2010

31. Rasheed S, Harris AL, Tekkis PP, et al: Hypoxia-inducible factor1alpha and -2alpha are expressed in most rectal cancers but only hypoxia-inducible factor-1alpha is associated with prognosis. Br J Cancer 100: 1666-1673. Erratum in: Br J Cancer 101: 742, 2009.

32. Vaupel P: The role of hypoxia-induced factors in tumor progression. Oncologist 9 (Suppl 5): 10-17, 2005.

33. Brökers N, Le-Huu S, Vogel S, Hagos Y, Katschinski DM and Kleinschmidt M: Increased chemoresistance induced by inhibition of HIF-prolyl-hydroxylase domain enzymes. Cancer Sci 101: 129-136, 2010.

34. DeClerck K and Elble RC: The role of hypoxia and acidosis in promoting metastasis and resistance to chemotherapy. Front Biosci 15: 213-225, 2010.

35. Bruick RK and McKnight SL: A conserved family of prolyl4-hydroxylases that modify HIF. Science 5545: 1337-1340, 2001

36. Hirsilä M, Koivunen P, Günzler V, Kivirikko KI and Myllyharju J: Characterization of the human prolyl 4-hydroxylases that modify the hypoxia-inducible factor. J Biol Chem 278 30772-30780, 2003.

37. Tuckerman JR, Zhao Y, Hewitson KS, Tian YM, Pugh CW, Ratcliffe PJ and Mole DR: Determination and comparison of specific activity of the HIF-prolyl hydroxylases. FEBS Lett 576: $145-150,2004$.

38. Roszak A, Kedzia W, Malkowska-Walczak B, Pawlik P, Kedzia H, Łuczak M, Lianeri M and Jagodzinski PP: Reduced expression of PHD2 prolyl hydroxylase gene in primary advanced uterine cervical carcinoma. Biomed Pharmacother (In press).

39. Fujimoto J, Alam SM, Jahan I, et al: Plausible linkage of hypoxia inducible factor-1alpha in uterine cervical cancer. Cancer Sci 97 861-867, 2006.

40. No JH, Jo H, Kim SH, et al: Expression of vascular endothelial growth factor and hypoxia inducible factor-1alpha in cervical neoplasia. Ann NY Acad Sci 1171: 105-110, 2009.

41. Niibe $\mathrm{Y}$, Watanabe J, Tsunoda S, et al: Concomitant expression of HER2 and HIF-1alpha is a predictor of poor prognosis in uterine cervical carcinoma treated with concurrent chemoradiotherapy: prospective analysis (KGROG0501). Eur J Gynaecol Oncol 31: 491-496, 2010.

42. Dellas K, Bache M, Pigorsch SU, et al: Prognostic impact of HIF-1alpha expression in patients with definitive radiotherapy for cervical cancer. Strahlenther Onkol 184: 169-174, 2008

43. Ishikawa H, Sakurai H, Hasegawa M, et al: Expression of hypoxic-inducible factor 1alpha predicts metastasis-free survival after radiation therapy alone in stage IIIB cervical squamous cell carcinoma. Int J Radiat Oncol Biol Phys 60: 513-521, 2004.

44. Hutchison GJ, Valentine HR, Loncaster JA, et al: Hypoxiainducible factor 1alpha expression as an intrinsic marker of hypoxia: correlation with tumor oxygen, pimonidazole measurements, and outcome in locally advanced carcinoma of the cervix. Clin Cancer Res 24: 8405-8412, 2004.

45. Burri P, Djonov V, Aebersold DM, et al: Significant correlation of hypoxia-inducible factor-1alpha with treatment outcome in cervical cancer treated with radical radiotherapy. Int J Radiat Oncol Biol Phys 56: 494-501, 2003.

46. Haugland HK, Vukovic V, Pintilie M, Fyles AW, Milosevic M, Hill RP and Hedley DW: Expression of hypoxia-inducible factor-1alpha in cervical carcinomas: correlation with tumor oxygenation. Int J Radiat Oncol Biol Phys 53: 854-861, 2002.

47. Vukovic V, Haugland HK, Nicklee T, Morrison AJ and Hedley DW: Hypoxia-inducible factor-1alpha is an intrinsic marker for hypoxia in cervical cancer xenografts. Cancer Res 61: 7394-7398, 2001.
48. Bache M, Reddemann R, Said HM, et al: Immunohistochemical detection of osteopontin in advanced head-and-neck cancer: prognostic role and correlation with oxygen electrode measurements, hypoxia-inducible-factor-1alpha-related markers, and hemoglobin levels. Int J Radiat Oncol Biol Phys 66: 1481-1487, 2006.

49. Razorenova OV, Finger EC, Colavitti R, et al: VHL loss in renal cell carcinoma leads to up-regulation of CUB domaincontaining protein 1 to stimulate $\mathrm{PKC}\{$ delta\}-driven migration. Proc Natl Acad Sci USA 108: 1931-1936, 2011.

50. Hatzimichael E, Dranitsaris G, Dasoula A, Benetatos L, Stebbing J, Crook T and Bourantas KL: Von Hippel-Lindau methylation status in patients with multiple myeloma: a potential predictive factor for the development of bone disease. Clin Lymphoma Myeloma 9: 239-242, 2009.

51. Schmitt AM, Schmid S, Rudolph T, et al: VHL inactivation is an important pathway for the development of malignant sporadic pancreatic endocrine tumors. Endocr Relat Cancer 16: 1219-1227, 2009.

52. Ghosh AK, Shanafelt TD, Cimmino A, et al: Aberrant regulation of pVHL levels by microRNA promotes the HIF/VEGF axis in CLL B cells. Blood 113: 5568-5574, 2009.

53. Stephen JK, Chen KM, Raitanen M, Grénman $S$ and Worsham MJ: DNA hypermethylation profiles in squamous cell carcinoma of the vulva. Int J Gynecol Pathol 28: 63-75, 2009.

54. Renbaum P, Duh FM, Latif F, Zbar B, Lerman MI and Kuzmin I: Isolation and characterization of the full-length 3' untranslated region of the human von Hippel-Lindau tumor suppressor gene. Hum Genet 98: 666-671, 1996.

55. Blagosklonny MV: Do VHL and HIF-1 mirror p53 and Mdm-2? Degradation-transactivation loops of oncoproteins and tumor suppressors. Oncogene 20: 395-398, 2001.

56. Karhausen J, Kong T, Narravula S and Colgan SP: Induction of the von Hippel-Lindau tumor suppressor gene by late hypoxia limits HIF-1 expression. J Cell Biochem 95: 1264-1275, 2005.

57. Pescador N, Cuevas Y, Naranjo S, Alcaide M, Villar D, Landázuri MO and Del Peso L: Identification of a functional hypoxiaresponsive element that regulates the expression of the egl nine homologue 3 (egln3/phd3) gene. Biochem J 390: 189-197, 2005.

58. Metzen E, Stiehl DP, Doege K, Marxsen JH, Hellwig-Bürgel T and Jelkmann W: Regulation of the prolyl hydroxylase domain protein 2 (phd2/egln-1) gene: identification of a functional hypoxia-responsive element. Biochem J 387: 711-717, 2005.

59. Henze AT, Riedel J, Diem T, et al: Prolyl hydroxylases 2 and 3 act in gliomas as protective negative feedback regulators of hypoxia-inducible factors. Cancer Res 70: 357-366, 2010.

60. Ginouvès A, Ilc K, Macías N, Pouysségur J and Berra E: PHDs overactivation during chronic hypoxia 'desensitizes' HIFalpha and protects cells from necrosis. Proc Natl Acad Sci USA 105: 4745-4750, 2008

61. Minamishima YA, Moslehi J, Padera RF, Bronson RT, Liao R and Kaelin WG Jr: A feedback loop involving the Phd3 prolyl hydroxylase tunes the mammalian hypoxic response in vivo. Mol Cell Biol 29: 5729-5741, 2009.

62. Qutub AA and Popel AS: Three autocrine feedback loops determine HIF1 alpha expression in chronic hypoxia. Biochim Biophys Acta 1773: 1511-1525, 2007.

63. Aprelikova O, Chandramouli GV, Wood M, et al: Regulation of HIF prolyl hydroxylases by hypoxia-inducible factors. J Cell Biochem 92: 491-501. Erratum in: J Cell Biochem 93: 639, 2004.

64. Marxsen JH, Stengel P, Doege K, et al: Hypoxia-inducible factor-1 (HIF-1) promotes its degradation by induction of HIF-alpha-prolyl-4-hydroxylases. Biochem J 381: 761-767, 2004.

65. Appelhoff RJ, Tian YM, Raval RR, et al: Differential function of the prolyl hydroxylases PHD1, PHD2, and PHD3 in the regulation of hypoxia-inducible factor. J Biol Chem 279: 38458-38465, 2004.

66. Berra E, Benizri E, Ginouvès A, Volmat V, Roux D and Pouysségur J: HIF prolyl-hydroxylase 2 is the key oxygen sensor setting low steady-state levels of HIF-1alpha in normoxia. EMBO J 22: 4082-4090, 2003.

67. D'Angelo G, Duplan E, Boyer N, Vigne P and Frelin C: Hypoxia up-regulates prolyl hydroxylase activity: a feedback mechanism that limits HIF-1 responses during reoxygenation. J Biol Chem 278: 38183-38187, 2003.

68. Kimura H, Weisz A, Ogura T, et al: Identification of hypoxiainducible factor 1 ancillary sequence and its function in vascular endothelial growth factor gene induction by hypoxia and nitric oxide. J Biol Chem 276: 2292-2298, 2001.

69. Wenger RH: Cellular adaptation to hypoxia: $\mathrm{O}_{2}$-sensing protein hydroxylases, hypoxia-inducible transcription factors, and $\mathrm{O}_{2}$-regulated gene expression. FASEB J 16: 1151-1162, 2002. 